\title{
INVESTIGATION OF A COMBINED GAS-STEAM SYSTEM WITH FLUE GAS RECIRCULATION
}

\author{
Tadeusz Chmielniak, Paweł Mońka*, Paweł Pilarz \\ Silesian University of Technology, Institute of Power Engineering and Turbomachinery, \\ ul. Konarskiego 18, 44-100 Gliwice, Poland
}

\begin{abstract}
This article presents changes in the operating parameters of a combined gas-steam cycle with a $\mathrm{CO}_{2}$ capture installation and flue gas recirculation. Parametric equations are solved in a purpose-built mathematical model of the system using the Ebsilon Professional code. Recirculated flue gases from the heat recovery boiler outlet, after being cooled and dried, are fed together with primary air into the mixer and then into the gas turbine compressor. This leads to an increase in carbon dioxide concentration in the flue gases fed into the $\mathrm{CO}_{2}$ capture installation from 7.12 to $15.7 \%$. As a consequence, there is a reduction in the demand for heat in the form of steam extracted from the turbine for the amine solution regeneration in the $\mathrm{CO}_{2}$ capture reactor. In addition, the flue gas recirculation involves a rise in the flue gas temperature (by $18 \mathrm{~K}$ ) at the heat recovery boiler inlet and makes it possible to produce more steam. These changes contribute to an increase in net electricity generation efficiency by $1 \%$. The proposed model and the obtained results of numerical simulations are useful in the analysis of combined gas-steam cycles integrated with carbon dioxide separation from flue gases.
\end{abstract}

Keywords: $\mathrm{CCS}$, combined cycle, rise in $\mathrm{CO}_{2}$ content in flue gases, flue gas recirculation, modelling

\section{INTRODUCTION}

Strategic plans of Polish power engineering modernisation and development focus mainly on replacing outdated production systems with new coal- and gas-fired power units and on upgrading existing installations to satisfy the standards of $\mathrm{NO}_{\mathrm{x}}, \mathrm{SO}_{2}, \mathrm{Hg}$ and dust emissions to the environment. The need to ensure uninterrupted supply of electrical energy and safety in delivery of fossil fuels leads to the energy mix diversification on the domestic market. Decisions to change the way of energy production are affected not only by plans of the energy-related companies but they also result from the government policy.

The growth in the use of natural gas for power generation is expected to have an impact on the reduction in the share of coal and on investment in units with random energy production (wind and solar energy). This is strongly related to the new EU regulations concerning emission limits and the energy market development. Combined power cycles which consist of gas and steam turbines are characterised by greater thermal flexibility, higher efficiencies and more reliable operation than conventional coal-fired units.

Power systems fired with natural gas have favourable environmental parameters because they generate less $\mathrm{CO}_{2}$ per unit of the fuel chemical energy during the combustion process $\left(0.055 \mathrm{~kg} \mathrm{CO}_{2} / \mathrm{MJ}\right.$ for 
methane combustion and $0.112 \mathrm{~kg} \mathrm{CO}_{2} / \mathrm{MJ}$ for coal). Considering the additional difference in electricity generation efficiency, it is clear that the gas technology has a huge advantage. Efficiency values are high and $\mathrm{CO}_{2}$ emissions are at the level of $325 \mathrm{~kg} / \mathrm{MWh}$. Additionally, due to the type of fuel and the way it burns, gas turbines involve much lower $\mathrm{SO}_{2}$ and $\mathrm{NO}_{\mathrm{x}}$ emissions compared to coal-based technologies.

Another advantage of gas-fired power units is the economic aspect. Investing in this field involves

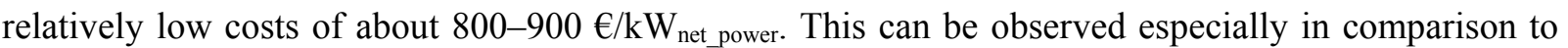
other power engineering technologies, where e.g. the unit price of building a steam power plant fired

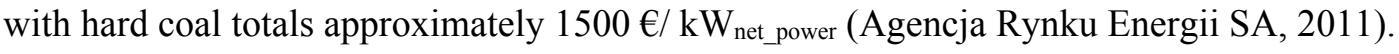

The only significant drawback of this technology in Poland is the relatively high price of the gas fuel. However, due to the fuel import diversification policy (e.g. the LNG terminal in Świnoujście) and the effort to find profitable shale gas deposits, a reduction in electricity production from natural gas can be expected. The far-reaching plans of the power sector companies assume an optimal solution in this area and investment in gas power capacities exceeding $400 \mathrm{MW}$ in the production facilities in EC Stalowa Wola, EC Żerań, EC Bydgoszcz, EC Grudziądz, Elektrownia Łagisza, PKE Orlen Włocławek, ZA Puławy. Energy production from natural gas totalled a 3.9\% share in the energy mix in 2012, but considering the implementation of the EU climate strategy supported by the Polish Energy Policy, a further growth in the gas share up to $6.6 \%$ in 2030 is expected or, as reported by the Energy Market Agency, even up to 10\% (Agencja Rynku Energii SA, 2011; Ministerstwo Gospodarki, 2009.

This paper presents a model of a combined cycle with flue gas recirculation applied to increase $\mathrm{CO}_{2}$ concentration. The rise in the amount of carbon dioxide leads to a decrease in energy intensity of $\mathrm{CO}_{2}$ capture in the chemical absorption process.

\section{2. $\mathrm{CO}_{2}$ REDUCTION}

Due to the considerable share of coal in the energy mix, the Polish power sector is characterised by a huge amount of environment pollution. The EU regulations require a reduction in the emissions of nitrogen oxides $\left(\mathrm{NO}_{\mathrm{x}}\right)$, sulphur dioxide, dust and, due to the alleged greenhouse effect, carbon dioxide. Because of this, investment is made in methods which increase the efficiency of energy generation from coal, in technologies for $\mathrm{CO}_{2}$ capture from flue gases and in construction of low- emission units.

Directive $2009 / 28 / \mathrm{EC}$, commonly referred to as the " $3 \times 20$ package", stipulates an obligation to increase energy efficiency by $20 \%$, achieve the $20 \%$ share of renewable sources in overall energy consumption and reduce the greenhouse gas emissions by $20 \%$ compared to the level of 1990 . In order to meet specific criteria, especially those concerning $\mathrm{CO}_{2}$ emissions, direct methods of reducing carbon dioxide emissions are being developed by means of technologies of carbon dioxide capture combined with its transport and storage (Carbon Capture and Storage - CCS technologies). There are three main ways to reduce $\mathrm{CO}_{2}$ emissions during the energy generation process: pre-combustion, oxy-combustion and post-combustion capture methods. Pre-combustion capture of carbon dioxide occurs before combustion. The fossil fuel is subjected to the process of gasification. The result is a synthetic gas (composed of $\mathrm{CO}$ and $\mathrm{H}_{2}$ ), which is processed further to obtain $\mathrm{CO}_{2}$ and $\mathrm{H}_{2} \mathrm{O}$. The $\mathrm{CO}_{2}$ obtained in this process is relatively pure and can be compressed and stored in geological formations. In the process of oxy-combustion, the fuel is burned with pure oxygen. This results in a significant increase in $\mathrm{CO}_{2}$ concentration in flue gases, which facilitates the gas further processing and condensation of water. This method is associated with the use of energy-intensive membranes separating $\mathrm{O}_{2}$ from the air (Skorek-Osikowska et al., 2014).

The post-combustion $\mathrm{CO}_{2}$ capture technology makes use of the process of chemical absorption of carbon dioxide from the flue gas stream in an aqueous solution of amines. The method was presented in 
detail using numerical modelling in (Asendrych et al., 2013). It is a highly energy-intensive process because a large heat flux is required to regenerate the $\mathrm{CO}_{2}$-amine solution. The average net electricity generation efficiency amounting to $10 \%$ also drops for hard coal-fired units. The energy intensity degree depends on the carbon dioxide concentration in the flue gases directed to the absorber. The relationship shown in Fig. 1 leads to the conclusion that the greater the content of $\mathrm{CO}_{2}$ in flue gases, the lower the energy consumption, and - consequently - the smaller the net efficiency drop in the system. The algorithm (1) presented in (Matuszewski et al., 2012) makes it possible to determine the energy of carbon dioxide separation from flue gases with a simplified composition $\left(\mathrm{CO}_{2}, \mathrm{~N}_{2}\right)$ and assumed carbon dioxide capture efficiency $\Theta=90 \%$ (Bochon and Chmielniak, 2014; Kotowicz and Job, 2013; Matuszewski et al., 2012).

$$
W_{\text {min }}=-\frac{R T_{0}}{\Theta}\left(\ln \left(\frac{1}{x_{\mathrm{CO}_{2}}}\right)+\frac{\left(1-\Theta x_{\mathrm{CO}_{2}}\right)}{x_{\mathrm{CO}_{2}}} \ln \left(\frac{1}{1-\Theta x_{\mathrm{CO}_{2}}}\right)+(1-\Theta) \ln (1-\Theta) x_{\mathrm{CO}_{2}}\right)
$$

The values shown in Fig. 1 are related to $1 \mathrm{~kg}$ of $\mathrm{CO}_{2}$ and they are calculated by means of a simplified model which takes account of the second law of thermodynamics and the substance constant and reversible flow, assuming that the potential and kinetic energy influence is negligible. The current state technology enables energy consumption at the level of $3.5 \mathrm{MJ} / \mathrm{kg} \mathrm{CO}$ with the $\mathrm{CO}_{2}$ mass content of about 21\% (Bochon and Chmielniak, 2014; Matuszewski et al., 2012).

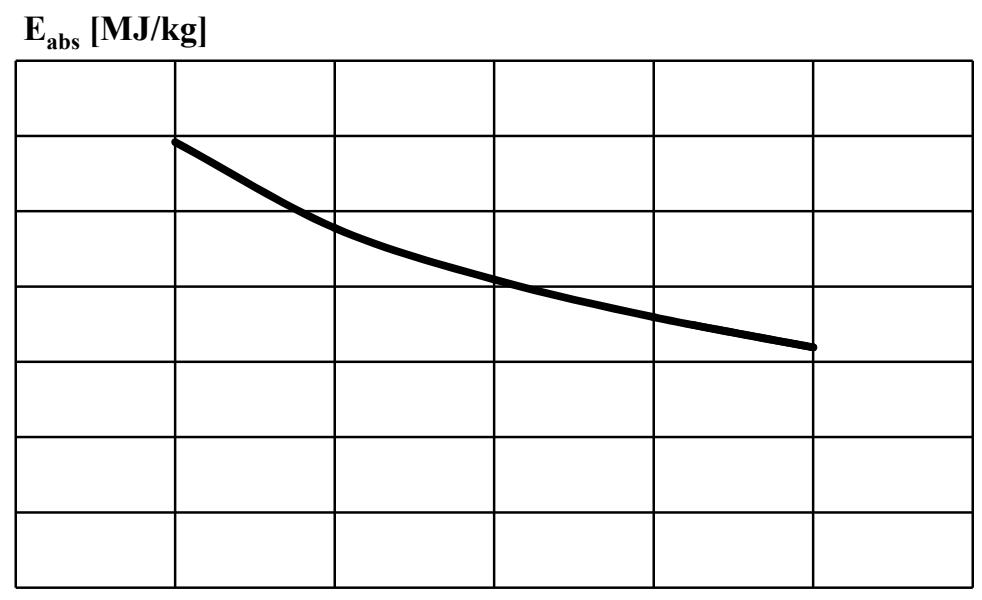

$$
\mathrm{X}_{\mathrm{CO} 2}[\%]
$$

Fig. 1. Energy consumption for chemical absorption of $1 \mathrm{~kg} \mathrm{CO}_{2}$ depending on $\mathrm{CO} 2$ concentration in flue gases

\section{FLUE GAS RECIRCULATION AND COOLING}

Designing a gas-steam system integrated with a carbon dioxide capture installation, an analysis should be conducted of the possibility of reducing the power unit own needs. A significant part of the needs is related to the functioning of the $\mathrm{CO}_{2}$ capture system and the energy consumed therein can be reduced. Gas combustion systems are characterised by a low mass content of $\mathrm{CO}_{2}$ in flue gases of $6-8 \%$, and this concentration is three times lower compared to that of coal-fired units. As shown in Fig. 1, the carbon dioxide concentration value has a substantial impact on the capture system energy consumption. In order to achieve better indices, $\mathrm{CO}_{2}$ concentration has to be increased. It can be accomplished by recirculating a part of the heat recovery steam generator (HRSG) flue gases to the node where it is mixed with primary air upstream the compressor.

The flue gases downstream the HRSG have the temperature of $80-100{ }^{\circ} \mathrm{C}$. For this reason, they have to be cooled down before they are mixed with primary air. The flue gas-air mixture high temperature 
would cause an increase in the gas turbine compressor power and a decrease in the system efficiency. To prevent this effect, flue gases are cooled by means of water injection, which makes it possible to achieve the predetermined temperature of $30^{\circ} \mathrm{C}$. After that, the flue gas stream is directed to the dryer and divider which is responsible for the degree of recirculation.

\section{DESCRIPTION OF THE ANALYSED COMBINED CYCLE}

The subject of this paper is a combined gas-steam system with flue gas recirculation integrated with an installation intended for chemical absorption of $\mathrm{CO}_{2}$ from flue gases. A diagram of the installation is presented in Fig. 2. A mathematical model was created in the EBSILON®Professional program, which was developed by Steag Energy Services GmbH. This enabled determination of the basic operating parameters and characteristics of the system under consideration, including electrical power and the own-needs index. Additionally, the EBSILON code made it possible to assess the impact of the flue gas recirculation on the system individual components.

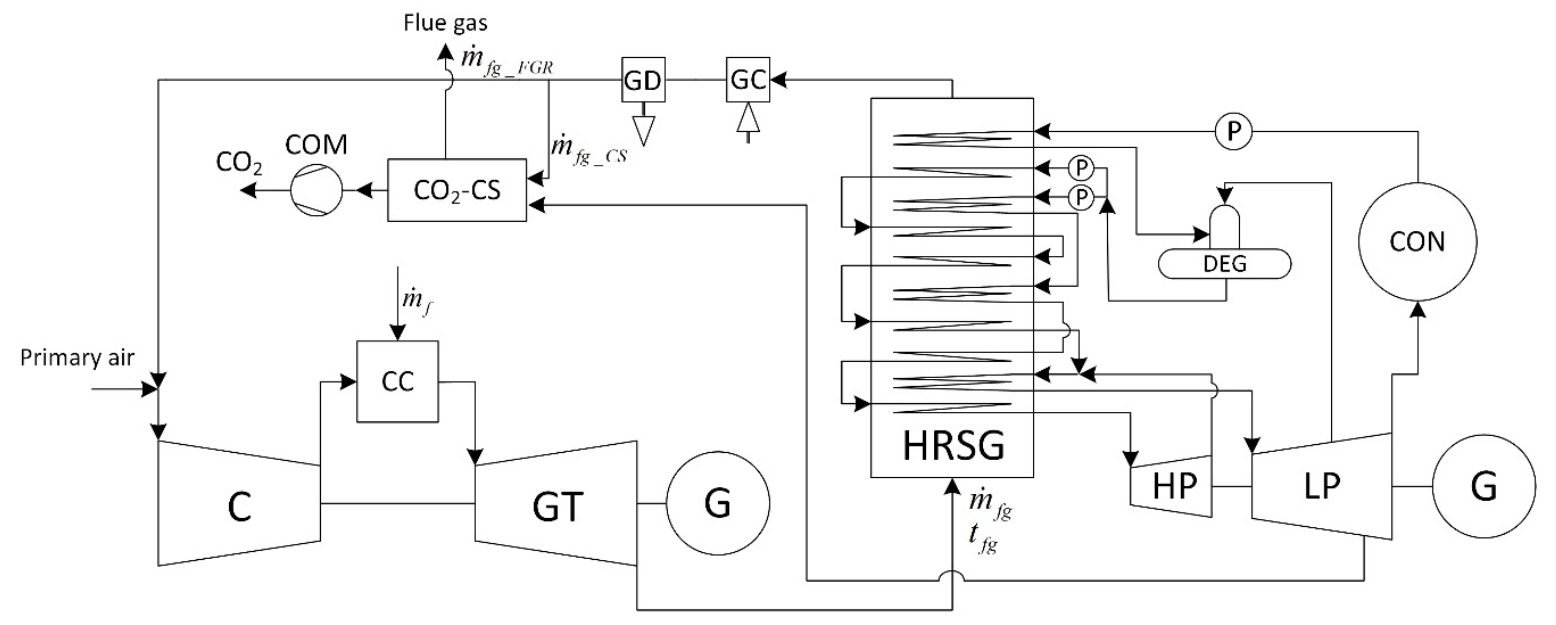

Fig. 2. Diagram of the analysed combined cycle with flue gas recirculation;

$\mathrm{C}$ - compressor, CC - combustion chamber, GT - gas turbine, G - generator, HRSG - heat recovery steam generator, $\mathrm{GC}$ - flue gas cooler, $\mathrm{GD}$ - flue gas dryer, $\mathrm{CO}_{2}-\mathrm{CS}-\mathrm{CO}_{2}$ capture system, $\mathrm{COM}-\mathrm{CO}_{2}$ compressor, DEG - degasser, CON - condenser, HP/LP steam turbine, $\mathrm{P}$ - pump

Three main component groups can be distinguished in the discussed system: the gas turbine, the waste heat boiler (HRSG) with the steam turbine and the $\mathrm{CO}_{2}$ capture installation $\left(\mathrm{CO}_{2}-\mathrm{CS}\right)$. The applied model of the gas turbine was described by Chmielniak and Mońka (2014). The "steam side" of the system is equipped with a two-part steam turbine (the high-pressure and the low-pressure part) driven by live and reheated steam with nominal pressure and temperature parameters of 150 bar and $550^{\circ} \mathrm{C}$ and 30 bar and $550{ }^{\circ} \mathrm{C}$, respectively. The degasser and the carbon dioxide capture installation are fed from the turbine two steam bleeds with the following parameters: $1.05 \mathrm{bar}, 160{ }^{\circ} \mathrm{C}$ (degasser) and 0.8 bar, $135^{\circ} \mathrm{C}$ (the $\mathrm{CO}_{2}$-CS installation), respectively.

The steam and water mixture is directed to the condenser with set pressure and cooling water values $\left(0.04\right.$ bar and $20^{\circ} \mathrm{C}$, respectively). Before being directed to the degasser, the condensate is preheated in a regenerative heat exchanger located at the end of the heat recovery boiler. The boiler is fed with the flue gas mass flow $\dot{m}_{f g}=40 \mathrm{~kg} / \mathrm{s}$ with temperature $t_{f g}=574{ }^{\circ} \mathrm{C}$, which produces the live and reheated steam mass flow of $4.2 \mathrm{~kg} / \mathrm{s}$ and $7.1 \mathrm{~kg} / \mathrm{s}$, respectively. The flue gases exiting the boiler with the temperature of $102{ }^{\circ} \mathrm{C}$ are directed to the cooler that fulfils two main functions. Firstly, it lowers the flue gas temperature to the level required by the $\mathrm{CO}_{2}-\mathrm{CS}$ installation to ensure the proper reaction 
between $\mathrm{CO}_{2}$ and amine. Secondly, due to the reduction in the flue gas temperature and - consequently - the change in the working medium specific volume, it makes it possible to reduce the consumption of energy needed to drive the gas turbine compressor. A decrease in temperature is achieved owing to a heat exchanger with water injection.

The cooled mixture of flue gases and water is directed to the dryer to separate water before it is fed further into the gas turbine compressor. Water is separated from the mixture using cyclone separators. The cyclone separator operation is based on the principle of mass forces (of inertia and gravity). The use of membrane heat exchangers is not recommended due to the large surface area of the heat transfer at a small temperature difference between the coolant and the cooled flue gases. The flue gas cooling temperature is assumed at $30^{\circ} \mathrm{C}$, according to the analysis made by Chmielniak and Mońka (2014). The cooled flue gas stream is separated and directed to the $\mathrm{CO}_{2}$-capture installation (CS) to remove carbon dioxide and to the node where it is mixed with primary air upstream the compressor. The mutual ratio of the flue gas two mass flows is described by the flue gas recirculation rate $F G R$ expressed by the ratio of the flue gas flow directed to the compressor $\left(\dot{m}_{f g_{-} F G R}\right)$ to the total flue gas mass flow emitted by the gas turbine $\left(\dot{m}_{f g}\right)$.

$$
F G R=\frac{\dot{m}_{f g_{-} F G R}}{\dot{m}_{f g}} \times 100 \%
$$

The flue gas recirculation rate $(F G R)$ is the input value in the described model, whereas the flue gas mass flow directed to the $\mathrm{CO}_{2}$ absorber $\dot{m}_{f g_{-} C S}$ is the resultant value equal to:

$$
\dot{m}_{f g_{-} C S}=\dot{m}_{f g}-\dot{m}_{f g_{-} F G R}
$$

Initially, for the mathematical model preliminary calculation, the $F G R$ value is $0 \%$ and the entire mass flow $\dot{m}_{f g_{-} C S}$ is directed to the stack and then to the atmosphere, bypassing the $\mathrm{CO}_{2}-\mathrm{CS}$ installation.

Such a setting of input parameters corresponds to the operation of a combined cycle without flue gas recirculation and with no $\mathrm{CO}_{2}$ capture system.

In subsequent simulations, an analysis is conducted of the effect of changing the flue gas recirculation rate $F G R(0 \%-50 \%)$ as well as of directing the entire mass flow $\dot{m}_{f g_{-} C S}$ to the carbon dioxide capture system on the combined gas-steam cycle operation with flue gas recirculation and a $\mathrm{CO}_{2}$ capture installation. The base value for the simulations is the constant mass flow of fuel (methane, $L H V \sim 50$ $\mathrm{MJ} / \mathrm{kg}$ ) of $1 \mathrm{~kg} / \mathrm{s}$. Additionally, all characteristic parameters of the gas turbine system, such as the compressor pressure ratio and the flue gas temperature at the gas turbine inlet are adopted according to the analysis performed by Chmielniak and Mońka (2014). The basic assumptions made for the combined gas-steam system calculations are listed in Table 1.

The main parameter of the assessment of the combined cycle (CC) operation efficiency is the net efficiency of electricity generation $\eta_{e l_{-} \text {net }}$, which is defined as follows:

$$
\begin{gathered}
\eta_{e l_{-} \text {net }}=\frac{N_{e l G T}+N_{e l S T}}{\dot{m}_{f} \times L H V} \\
N_{e l G T}=\left(N_{i G T} \times \eta_{m G T}-\frac{N_{i C}}{\eta_{m C}}\right) \times \eta_{G} \\
N_{e l S T}=N_{i S T} \times \eta_{m S T} \times \eta_{G}
\end{gathered}
$$

The characteristic operating parameters of the combined gas-steam cycle (without flue gas recirculation and with no carbon dioxide capture installation) obtained from the mathematical model for the assumptions listed in Table 1 are presented in Table 2. 
Table 1. Assumptions for the combined cycle calculations

\begin{tabular}{|c|c|c|}
\hline Parameter & Unit & Value \\
\hline Fuel mass flow, $\dot{m}_{f}$ & $\mathrm{~kg} / \mathrm{s}$ & 1 \\
\hline Fuel Lower Heating Value, $L H V$ & $\mathrm{MJ} / \mathrm{kg}$ & 50.015 \\
\hline Flue gas recirculation rate, $F G R$ & $\%$ & 0 \\
\hline Steam mass flow to the CCS system, $\dot{m}_{s_{-} C S}$ & $\mathrm{~kg} / \mathrm{s}$ & 0 \\
\hline Cooling temperature in the flue gas cooler & ${ }^{\circ} \mathrm{C}$ & 30 \\
\hline Temperature downstream the combustion chamber & ${ }^{\circ} \mathrm{C}$ & 1400 \\
\hline Compressor pressure ratio, $\beta$ & - & 18 \\
\hline Gas turbine isentropic efficiency, $\eta_{i G T}$ & $\%$ & 90 \\
\hline Gas turbine mechanical efficiency, $\eta_{m G T}$ & $\%$ & 99 \\
\hline Compressor isentropic efficiency, $\eta_{i C}$ & $\%$ & 88 \\
\hline Compressor mechanical efficiency, $\eta_{m C}$ & $\%$ & 99 \\
\hline Live steam temperature & ${ }^{\circ} \mathrm{C}$ & 550 \\
\hline Live steam pressure & bar & 150 \\
\hline Steam turbine isentropic efficiency, $\eta_{i S T}$ & $\%$ & 90 \\
\hline Condensate pump isentropic efficiency, $\eta_{i C P}$ & $\%$ & 85 \\
\hline Steam turbine mechanical efficiency, $\eta_{m S T}$ & $\%$ & 99 \\
\hline Generator efficiency, $\eta_{G}$ & $\%$ & 99 \\
\hline Condenser pressure & bar & 0.04 \\
\hline Flue gas pressure downstream the gas turbine & bar & 1.16 \\
\hline $\mathrm{CO}_{2}$ compression pressure & bar & 150 \\
\hline Live steam pressure drop in the HRSG & bar & 0.2 \\
\hline Reheat steam pressure drop in the HRSG & bar & 0.25 \\
\hline Flue gas pressure drop in the HRSG & bar & 0.01 \\
\hline Temperature of water injection in the flue gas cooler & ${ }^{\circ} \mathrm{C}$ & 12 \\
\hline Ambient temperature & ${ }^{\circ} \mathrm{C}$ & 15 \\
\hline Ambient pressure & bar & 1.15 \\
\hline
\end{tabular}

Table 2. Selected characteristic operating parameters of the gas-steam system

\begin{tabular}{|l|c|c|}
\hline Parameter & Unit & Value \\
\hline Combined cycle electricity generation efficiency, $\eta_{e l C C}$ & $\%$ & 59.13 \\
\hline Gas turbine electricity generation efficiency, $\eta_{e l G T}$ & $\%$ & 39.98 \\
\hline Gas turbine net electrical power, $N_{e l G T}$ & $\mathrm{MW}$ & 19.52 \\
\hline Steam turbine net electrical power, $N_{e l S T}$ & $\mathrm{MW}$ & 10.10 \\
\hline Compressor internal power, $N_{m C}$ & $\mathrm{MW}$ & 16.92 \\
\hline Flue gas temperature at the gas turbine outlet, $t_{f g}$ & ${ }^{\circ} \mathrm{C}$ & 574 \\
\hline Flue gas temperature at the HRSG outlet & ${ }^{\circ} \mathrm{C}$ & 102 \\
\hline $\mathrm{CO}_{2}$ content in flue gas, $X_{\mathrm{CO}_{2}}$ & ${ }^{\mathrm{wt}} \%$ & 7.12 \\
\hline
\end{tabular}




\section{INFLUENCE OF SELECTED PARAMETERS ON THE SYSTEM OPERATION}

In order to simulate the operation of a real combined gas-steam cycle as accurately as possible, a sensitivity analysis was performed of the effect of changes in selected values of the model input data. In particular, the analysis concerned the flue gas recirculation rate, the mass flow of steam feeding the carbon dioxide capture system and the working medium amount in the steam cycle. The model input variables and the basic parameters of the system operation assessment are presented in Table 3. The first highlighted column presents data for the combined cycle without flue gas recirculation and with no $\mathrm{CO}_{2}$-CS installation.

Table 3. Selected parameters of the modelled combined cycle

\begin{tabular}{|c|c|c|c|c|c|c|c|}
\hline \multirow{2}{*}{ Parameter } & Unit & \multicolumn{7}{|c|}{ Input data } \\
\hline$F G R$ & $\%$ & 0 & 0 & 13 & 26 & 39 & 50 \\
\hline$\dot{m}_{f g_{-} C S}$ & $\mathrm{~kg} / \mathrm{s}$ & 0 & 6.11 & 5.99 & 5.65 & 5.24 & 4.69 \\
\hline$\dot{m}_{w}$ & $\mathrm{~kg} / \mathrm{s}$ & 7.02 & 7.02 & 7.08 & 7.15 & 7.23 & 7.35 \\
\hline Parameter & Unit & \multicolumn{7}{|c|}{ Output data } \\
\hline$\eta_{\text {elCC }}$ & $\%$ & 59.13 & 51.43 & 51.50 & 51.74 & 52.02 & 52.40 \\
\hline$\eta_{\text {elGT }}$ & $\%$ & 38.98 & 38.98 & 38.82 & 38.63 & 38.40 & 38.07 \\
\hline$N_{\text {elGT }}$ & MW & 19.51 & 19.51 & 19.43 & 19.34 & 19.22 & 19.06 \\
\hline$N_{m C}$ & MW & 16.92 & 16.92 & 16.96 & 16.96 & 16.89 & 16.68 \\
\hline$N_{\text {elST }}$ & MW & 10.10 & 7.75 & 7.87 & 8.08 & 8.33 & 8.69 \\
\hline
\end{tabular}

As shown in Table 3, the operation of a $\mathrm{CO}_{2}$ capture installation involves a decrease in the net electricity generation efficiency by 7.7 percentage points - to the value of $51.43 \%$. The presented drop in efficiency is lower compared to coal-fired power units mainly due to the twice lower generation of $\mathrm{CO}_{2}$ molecules per the fuel chemical energy $\left(0.055 \mathrm{CO}_{2} / \mathrm{MJ}\right)$. Another disadvantage of gas-fired units is the almost three times lower $\mathrm{CO}_{2}$ concentration in flue gases.

\subsection{FGR impact on flue gas temperature and content of $\mathrm{CO}_{2}$}

The data presented in Table 3 point to a decrease in the gas turbine electric power and in the compressor mechanical power. The changes can be explained by two phenomena.

Firstly, an increase in flue gas recirculation involves a change in the mass fractions of gases directed to the gas turbine (mainly $\mathrm{N}_{2}$ and $\mathrm{CO}_{2}$ ). These gases have different adiabatic exponents. Consequently, and according to the Poisson law describing the process of an adiabatic change, differences may arise in expansion curves of gases with a different number of molecules, and this may result in changes of in the gas turbine operation.

Secondly, a change in the $F G R$ value involves a change in the temperature of flue gases directed to the compressor. The temperature results from the ambient temperature value and from the temperature of cooled flue gases, taking account of the respective mass flow values. The lowest temperature of $15^{\circ} \mathrm{C}$ was obtained for $F G R=0 \%$, whereas the highest value of $23^{\circ} \mathrm{C}-$ for $F G R=50 \%$. 
Additionally, the different structure of di- and triatomic molecules and the different adiabatic exponent mentioned above contribute to obtaining different flue gas temperatures at the gas turbine outlet. Fig. 3 illustrates changes in the flue gas temperature depending on the recirculation rate $(F G R)$.

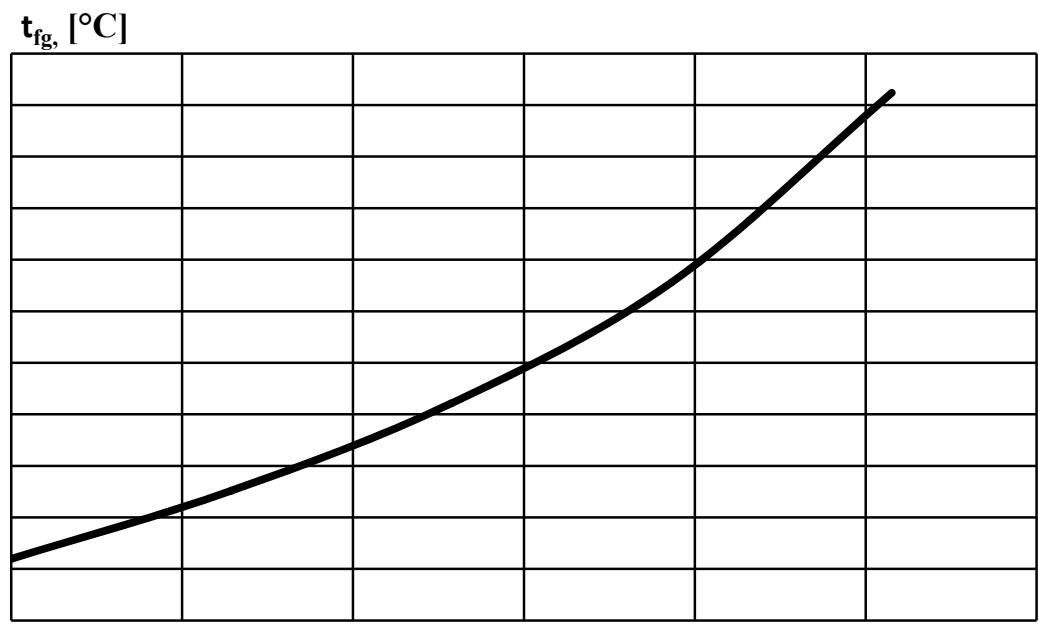

Flue gas recirculation rate, FGR [\%]

Fig. 3. The gas turbine flue gas temperature depending on the FGR

Considering the rise in the flue gas temperature, the steam cycle feed water mass flow was optimised to collect more heat in the waste heat boiler at constant steam parameters. As a consequence, the feed water mass flow $\left(\dot{m}_{w}\right)$ was increased by $4.7 \%$ for $\mathrm{R}=50 \%$, which was accompanied by an increase in the steam part electric power by $0.94 \mathrm{MW}$.

The dependence of the $\mathrm{CO}_{2}$ mass fraction in flue gases on the recirculation rate was also observed, as illustrated in Fig. 4. The simulation results are consistent with the information included in the introduction section of this article. Recirculation of a half of the flue gas mass flow involves more than a double increase in the $\mathrm{CO}_{2}$ content in flue gases, which ultimately reaches the value of $X_{\mathrm{CO}_{2}}=15.7 \%$ for $F G R=50 \%$.

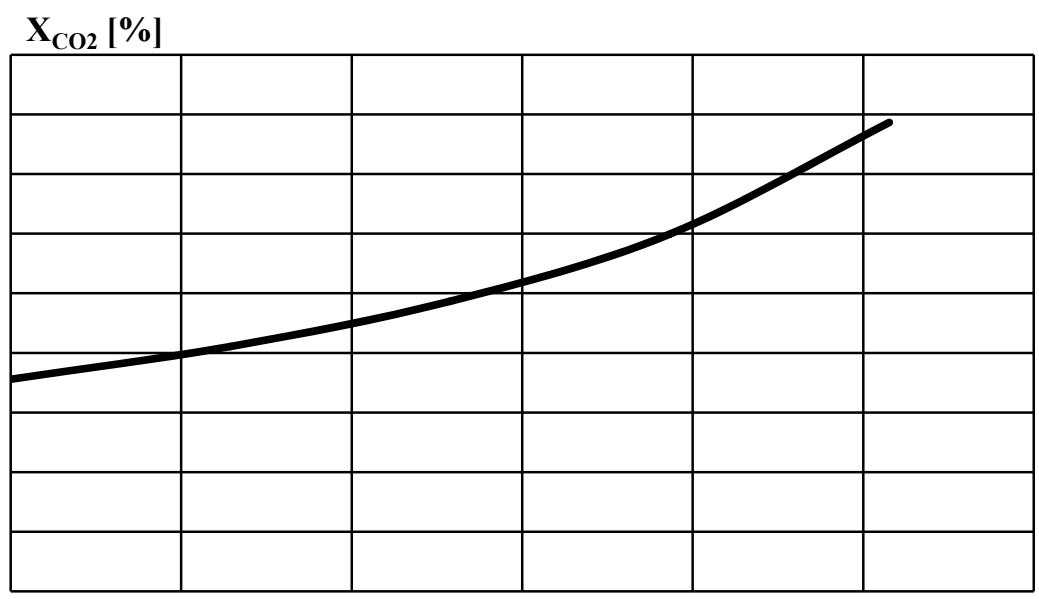

Flue gas recirculation rate FGR [\%]

Fig. 4. $\mathrm{CO}_{2}$ fraction in flue gases depending on the recirculation rate

Simultaneously, taking account of the data from Fig. 1, it is possible to decrease the CCS installation energy consumption by as much as $24 \%$, which was implemented in the model according to Table 3 . 


\subsection{FGR effect on the combined cycle net electricity generation efficiency}

The main parameter of the combined cycle operation effectiveness assessment is the rise in the net electricity generation efficiency. Analysing the relationship illustrated in Fig. 5, it may be noticed that recirculation at the rate of $F G R=50 \%$ leads to an increase in efficiency by 1 percentage point. At the current stage of work it is difficult to say whether this improvement in efficiency is sufficient to make a decision to implement the proposed solution in commercial installations. It should be remembered that some of the assumptions made herein may have affected the obtained results. Among others, the assumed desorption energy consumption is to a certain extent an empirical value and in reality lower values may be the case. Moreover, numerous research works are being carried out to obtain synthetic amines characterised by recovery heat of $1.3 \mathrm{MJ} / \mathrm{kg} \mathrm{CO}_{2}$ (Chowdhury et al., 2011), which is only about $37 \%$ of the value assumed in this paper (MEA - monoethanolamine, $3.5 \mathrm{MJ} / \mathrm{kg} \mathrm{CO}_{2}$ ).

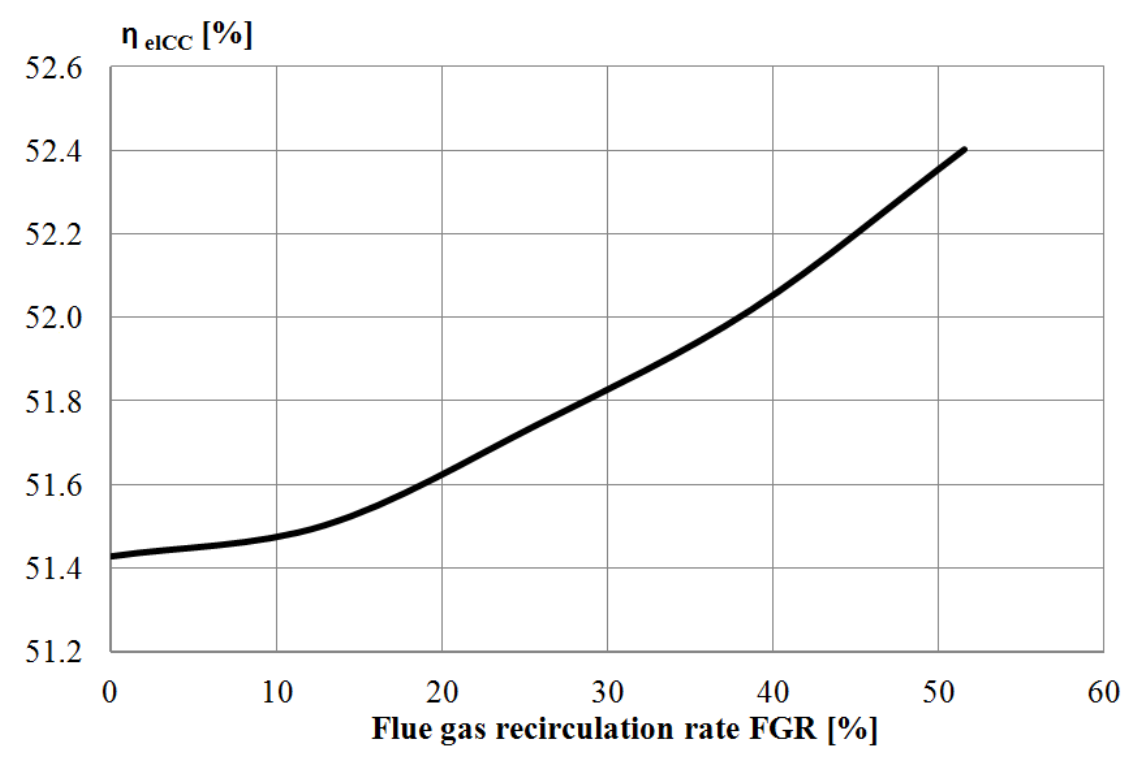

Fig. 5. Combined cycle net electricity generation efficiency depending on the flue gas recirculation rate

The negative aspects of this analysis include the difficulties in the efficient cooling of flue gases. It is required not only for the compressor proper operation, but also for the CCS installation purposes. Based on the analysis of the operation of the combined cycle with flue gas recirculation, it can be concluded that the results obtained from the mathematical model are correct and they may be confirmed on an industrial scale. However, before the final assessment is made, a feasibility study with a thorough economic analysis should be performed.

\subsection{Impact of changes in power load on the combined cycle net electricity generation efficiency}

An important feature of the paper is its focus on the flexibility of the power unit operation under variable loads. The power unit must be able to respond to such changes relatively fast and feature high flexibility of operation required to maintain the power grid stability. In addition, a drop in efficiency is an important indicator if the system operates under a partial load.

Figure 6 shows the efficiency of the combined cycle as a function of the load change (within the range of $50-105 \%$ of the fuel mass flow) for three levels of the $F G R$. It can be seen that the described model predicts a decrease in efficiency by 6.79 percentage points (for $F G R=0 \%$ ). For $F G R=25 \%$ and $F G R=50 \%$, a decrease in the net electricity generation efficiency by about 6.76 and 6.66 percentage points can be observed for the drop in power by $30 \%$ from the reference point (best efficiency point). 
$\eta_{\mathrm{el}, \mathrm{CC}}[\%]$

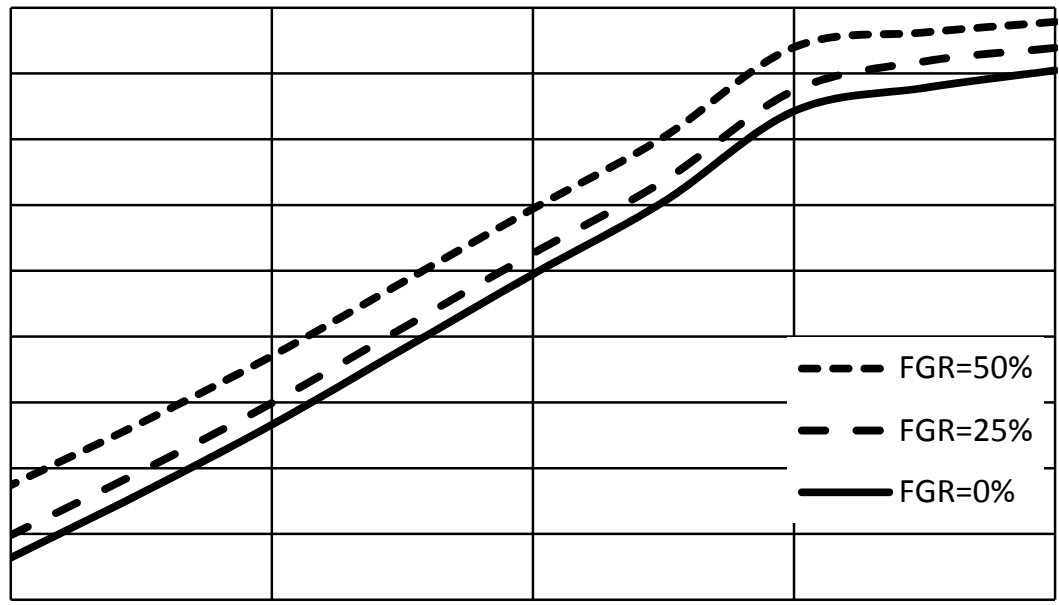

Power load [\%]

Fig. 6. Combined cycle net electricity generation efficiency depending on changes in the power load

\section{CONCLUSIONS}

This article presents the change in the operating parameters of the combined gas-steam cycle with a $\mathrm{CO}_{2}$ capture installation and flue gas recirculation. The main idea of the paper was to increase the efficiency of the power plant integrated with a carbon dioxide capture and storage system. This target is achieved using flue gas recirculation.

The study was based on a mathematical model built using the Ebsilon ${ }^{\circledR}$ Professional code, which enabled parametric simulations. The code also made it possible to determine the model basic parameters and characteristics and to assess the impact of the flue gas recirculation on the system individual components.

The paper presents the consumption of energy needed for chemical absorption in the CCS installation as a function of $\mathrm{CO}_{2}$ concentration in flue gases. It is possible to double $\mathrm{CO}_{2}$ concentration in flue gases (from $7 \%$ to $15 \%$ ) but the FGR has to be maintained at the level of 50\%. Consequently, the demand for heat (in the form of steam extracted from the turbine for the amine solution regeneration in the $\mathrm{CO}_{2}$ capture system) is reduced. The steam turbine can generate more electricity. An increase by 1 percentage point in the net electricity generation efficiency can be observed. In addition, the recirculated flue gas stream involves a rise in the flue gas temperature by about $20^{\circ} \mathrm{C}$ at the waste heat boiler inlet. The higher temperature makes it possible to produce more steam (at the steam constant temperature). As a result, the steam turbine electric power rises by about $0.94 \mathrm{MW}$.

The mixture of recirculated flue gases and primary air is directed to the gas turbine compressor. Flue gases must be cooled to a lower temperature (here: to $30^{\circ} \mathrm{C}$ ) to ensure the compressor highly efficient operation. In this paper a decrease in the compressor mechanical power is observed. This is due to the increase in the flue gas recirculation, which leads to a change in the mass fractions of gases directed to the compressor. According to the Poisson law, differences may arise in the gas compression curves and in other characteristics of the compressor operation.

The developed model and the obtained results are useful in the analysis of combined gas-steam cycles integrated with carbon dioxide separation from flue gases. The concept of the combined system upgrade presented in this paper may be useful for newly constructed power units, especially in the light of the applicable law concerning "CCS Ready" power plants. A flue gas recirculation installation may 
improve the financial performance of both new power units and upgraded facilities. Further research is necessary to estimate the investment cost.

The results presented in this paper were obtained from research work co-financed by the Polish National Centre of Research and Development within the framework of Contract SP/E/1/67484/10 Strategic Research Programme - Advanced technologies for obtaining energy: Development of a technology for highly efficient zero-emission coal-fired power units integrated with $\mathrm{CO}_{2}$ capture.

\section{SYMBOLS}

LHV fuel lower heating value, $\mathrm{MJ} / \mathrm{kg}$

$\dot{m}_{f} \quad$ fuel mass flow, $\mathrm{kg} / \mathrm{s}$

$N_{\text {elGT }} \quad$ gas turbine net electric power, MW

$N_{\text {elST }} \quad$ steam turbine net electric power, MW

$N_{i C} \quad$ compressor internal power, MW

$N_{i G T} \quad$ gas turbine internal power, MW

$N_{i S T} \quad$ steam turbine internal power, MW

$t_{f g} \quad$ flue gas temperature, ${ }^{\circ} \mathrm{C}$

$X_{\mathrm{CO}_{2}} \quad \mathrm{CO}_{2}$ mass fraction in flue gas, $\%$

Greek symbols

$\eta_{\text {elCC }} \quad$ combined cycle electricity generation efficiency, $\%$

$\eta_{G} \quad$ generator mechanical efficiency, $\%$

$\eta_{m C} \quad$ compressor mechanical efficiency, $\%$

$\eta_{m G T} \quad$ gas turbine mechanical efficiency, $\%$

$\eta_{m S T} \quad$ steam turbine mechanical efficiency, $\%$

\section{REFERENCES}

Agencja Rynku Energii S.A., 2011. Aktualizacja prognozy zapotrzebowania na paliwa i energie do roku 2030 (Update of the forecast for the demand for fuels and energy till 2030). Warszawa. Available at: http://www.me.gov.pl/files/upload/11099/ARE\%20MG_2011_Raport_koncowy_01_09_2011.pdf

Asendrych D., Niegodajew P., Drobniak S., 2013. CFD modelling of $\mathrm{CO}_{2}$ capture in a packed bed by chemical absorption. Chem. Process Eng., 34, 269-282. DOI: 10.2478/cpe-2013-0022.

Bochon K., Chmielniak T., 2014. Energy analysis of CO2 capture installation including the work at variable load. Rynek Energii, 1(110)/2014, 96-103 (in Polish).

Chmielniak T., Mońka P., 2014. Analysis of a gas turbine system with flue gas recirculation. 22nd Convention of Thermodynamics Engineers, Polańczyk, Poland, 23-27.09.2014 (in Polish).

Chowdhury F.A., Okabe H., Yamada H., Onoda M., Fujioka Y., 2011. Synthesis and selection of hindered new amine absorbents for $\mathrm{CO}_{2}$ capture. Energy Procedia, 4, 201-208. DOI:10.1016/j.egypro.2011.01.042.

Kotowicz J., Job M., 2013. Zero-emission gas-steam power plant with oxy-combustion and a single-pressure waste heat boiler. 3rd Science and Technology Conference. Cracow, Poland, 16-18.10.2013 (in Polish).

Matuszewski, M., Ciferno, J., Chen, S., 2012. Research and development goals for $\mathrm{CO}_{2}$ capture technology. US Dept. of Energy, National Energy Technology Laboratory.

Ministerstwo Gospodarki, 2009. Polityka energetyczna Polski do 2030 roku. Appendix to Resolution 202/2009 of the Council of Ministers of 10 November 2009, Warszawa. Available at: http://www.mg.gov.pl/files/upload/8134/Polityka\%20energetyczna\%20ost.pdf. 
Skorek-Osikowska A., Bartela Ł., Kotowicz J., 2014. Influence of the selected parameters on the effectiveness of IGCC system integrated with CCS installation. Chem. Process Eng., 35, 233-248. DOI:10.2478/cpe-2014-0018.

Received 08 April 2015

Received in revised form 27 April 2016

Accepted 27 April 2016 